Geology, Geophysics \& Environment • $2012 \bullet$ Vol. 38 • No. 2 • 239-250

http://dx.doi.org/10.7494/geol.2012.38.2.239

\title{
WYROBISKA SOLNE JAKO PRZESTRZEŃ URBANISTYCZNA
}

\author{
Salt workings as urban spaces
}

\section{Piotr LANGER}

\author{
Instytut Projektowania Miast i Regionów, Wydział Architektury Politechniki Krakowskiej; \\ ul. Warszawska 24, 30-155 Kraków; e-mail:piotrlanger@pro.onet.pl
}

Treść: W artykule zwrócono uwagę na szczególne znaczenie wyrobisk solnych w nieczynnych kopalniach soli, które ze względu na specyficzne cechy i walory mogą być wykorzystywane do stymulowania rozwoju i wzmacniania atrakcyjności górniczych miast solnych jako ośrodków poprzemysłowych. Podkreślono potrzebę wyboru odpowiedniego kierunku przebudowy i adaptacji wyrobisk solnych w celu możliwie pełnego wyeksponowania i zachowania unikatowych wartości oraz udostępnienia kopalni różnym grupom użytkowników.

Słowa kluczowe: kopalnie soli, wyrobiska solne, miasta i regiony solne, adaptacja funkcjonalna, rozwój zrównoważony, dziedzictwo salinarne

\begin{abstract}
This paper points out particular significance of salt workings in abandoned salt mines which, owing to specific features and values, can be used for stimulation of the development and the increase of the attractiveness of salt mining towns as former industrial centres. The authors emphasized the need of choice of a proper direction of remodelling and adaptation of salt workings to attain possibly a complete display and preservation of unique values, with making the salt mine available to various types of users.
\end{abstract}

Key words: salt mines, salt workings, salt towns and regions, functional adaptation, sustainable development, salinar heritage

\section{WPROWADZENIE}

W dyskusji nad obecnym stanem i perspektywami rozwoju polskiego górnictwa solnego, istniejące kopalnie podziemne są zazwyczaj rozpatrywane wyłącznie jako obiekty przemysłowe. Zarówno badania naukowe, jak i działania praktyczne skupiają się na uwarunkowaniach górniczej eksploatacji soli kamiennych różnymi metodami, a także obejmują techniczne, ekonomiczne i prawne aspekty procesu likwidacji nieczynnych zakładów górniczych. Jednocześnie coraz większego znaczenia nabierają badania nad praktycznym wykorzystaniem zidentyfikowanych struktur solnych oraz zachowanych wyrobisk górniczych niektórych kopalni na potrzeby nowoczesnego magazynowania i składowania. W badaniach tych często pomija się wzajemne relacje systemów wyrobisk podziemnych w kopalniach soli i miast górniczych, traktując te struktury jako elementy odrębne i niezależne. Zwraca 
się natomiast dużą uwagę na niszczący wpływ eksploatacji górniczej, uznając tym samym kopalnie soli za obiekty niosące istotne zagrożenie dla przestrzeni.

W okresie trwania przemysłowej eksploatacji soli znaczenie kopalni dla miast jest na ogół rozpatrywane w kategoriach gospodarczych, ponieważ działalność górnicza stwarza miejsca pracy i w założeniu ma przynosić zysk ekonomiczny. Ogląd ten ulega jednak diametralnej zmianie po zakończeniu eksploatacji soli i przystąpieniu do procesu częściowej lub całkowitej likwidacji kopalni. Istniejący system podziemnych wyrobisk solnych, a także zachowana infrastruktura górnicza na powierzchni terenu, stają się wtedy trudnym do rozwiązania problemem, zazwyczaj elementem niepożądanym w przestrzeni miejskiej.

Niniejszy artykuł ma na celu zwrócenie uwagi na walory i znaczenie podziemnych wyrobisk eksploatacyjnych w kopalniach soli, jako specyficznego, a nawet unikatowego dziedzictwa poprzemysłowego, które w miarę możliwości technicznych i ekonomicznych powinno być eksponowane i wykorzystywane we współczesnym rozwoju miast solnych.

Artykuł powstał głównie w efekcie własnych prac terenowych prowadzonych w ośrodkach górnictwa solnego, zarówno funkcjonujących jak i poprzemysłowych, w Polsce oraz innych krajach europejskich - Niemczech, Austrii, Ukrainie i Słowacji. Ponadto analizę możliwości i współczesnych kierunków adaptacji funkcjonalnej wyrobisk solnych sporządzono również na podstawie literatury przedmiotu (m.in.: Czapowski et al. 2004, 2006, Kunstman et al. 2005, Marx et al. 2005, Markiewicz et al. 2006).

\section{KOPALNIE SOLI I GÓRNICZE MIASTA SOLNE}

Rozpatrując historyczne związki pomiędzy obiektami przemysłowymi pozyskującymi sól a miastami, w których obiekty te się znajdują, można zauważyć, że pozyskiwanie soli różnymi metodami - najpierw w salinach morskich i warzelniach, a w późniejszym okresie technikami górniczymi, było w przeszłości istotnym czynnikiem miastotwórczym. W pobliżu lub bezpośrednim sąsiedztwie salin, warzelni i podziemnych kopalni soli powstawały i rozwijały się miasta czerpiące zyski z handlu solą oraz obsługujące salinarną działalność przemysłową. W grupie tych miast wyraźną specyfiką cechują się ośrodki górnicze, gdzie zabudowa miejska często pozostaje w silnych relacjach z inną strukturą przestrzenną - systemem podziemnych wyrobisk solnych, tworząc zespolony układ dwóch elementów wzajemnie zależnych, chociaż „wybudowanych” na różnych poziomach.

Badania prowadzone przez autora w europejskich ośrodkach górnictwa solnego jednoznacznie wykazały, że działalność podziemnych kopalni soli, prowadzona w niektórych miastach nieprzerwanie przez wiele stuleci, odegrała w tych miastach kluczową rolę nie tylko w sferze gospodarczej i ekonomicznej, ale również w sensie przestrzennym, kulturowym i społecznym. Podziemne górnictwo solne, jako gałąź przemysłu o bogatej historii i długiej drodze ewolucyjnej, zapisało się trwale i czytelnie $\mathrm{w}$ przestrzeni miast solnych. Zróżnicowane dziedzictwo salinarne, obejmujące zarówno elementy materialne, jak i wpływające na kulturę oraz nastrój miasta, decyduje o współczesnej tożsamości i specyfice przestrzeni miejskiej, nawet po całkowitym zaprzestaniu przemysłowej działalności 
w kopalni soli. Wśród wielu elementów tego dziedzictwa niewątpliwie największe znaczenie mają górnicze wyrobiska solne o różnorodnych formach i układach. Specyficzne cechy wyrobisk oraz wynikające $\mathrm{z}$ tych cech możliwości wielokierunkowej adaptacji funkcjonalnej nieczynnych kopalni soli nadają przestrzeniom poeksploatacyjnym nowego znaczenia. Wyrobiska solne mogą być współcześnie rozpatrywane jako nietypowe przestrzenie urbanistyczne, będące interesującym poszerzeniem struktury miejskiej i stanowiące dla miast górniczych znaczącą wartość dodaną o wyjątkowych walorach i dużym potencjale adaptacyjnym.

\section{SPECYFIKA WYROBISK SOLNYCH JAKO PODSTAWA ICH ADAPTACJI FUNKCJONALNEJ}

Wyjątkowe właściwości oraz cechy soli kamiennej - jako związku chemicznego, minerału i skały - a także nietypowa, często złożona budowa geologiczna struktur solnych zadecydowały o wyraźnej odmienności wyrobisk górniczych w kopalniach soli na tle kopalni eksploatujących inne kopaliny - węgiel kamienny, rudy metali, złoto czy srebro.

Do najważniejszych cech decydujących o specyficznym charakterze podziemnych wyrobisk solnych należą:

- zróżnicowanie układów przestrzennych wyrobisk jako pochodna budowy geologicznej złóż soli, metody eksploatacji i czasu jej trwania, obejmujące systemy o złożonej formie organicznej i regularnej formie ortogonalnej (Fig. 1);

- unikatowe walory widokowe wyrobisk solnych - przestrzeni o zróżnicowanych kształtach, wielkościach i proporcjach, rozplanowanych na wielu poziomach, wzajemnie ze sobą połączonych, często nieobudowanych, ukazujących naturalne utwory skalne o różnorodnych barwach i fakturach, a także imponujące struktury polikrystaliczne oraz formacje solne tworzące się w różnych warunkach i okresach geologicznych;

- mikroklimat panujący w obrębie wyrobisk solnych, cechujący się stałą temperaturą i wilgotnością oraz ujemną jonizacją powietrza, niezależny od pór roku i warunków pogodowych panujących na powierzchni terenu;

- wartość historyczna wyrobisk solnych, drążonych w wielu miejscach nieprzerwanie przez całe stulecia, odzwierciedlających w swej formie długą drogę ewolucji górniczej metody eksploatacji soli kamiennej, przy użyciu różnych technik i narzędzi, także współczesnych;

- duża czystość powietrza atmosferycznego wypełniającego podziemia kopalni soli, prawie pozbawionego zanieczyszczeń chemicznych i biologicznych, a jednocześnie zawierającego jony pierwiastków niezbędnych do prawidłowego funkcjonowania ludzkiego organizmu;

- niepowtarzalny nastrój panujący w wyrobiskach podziemnych, budzący z jednej strony grozę, a z drugiej - fascynację, potęgowany przez panujący półmrok i grę świateł oraz niecodzienne wrażenia zmysłowe - głęboką ciszę, odgłosy odbijające się echem, słonawy lub gorzkawy posmak, specyficzny zapach, a także wyraźnie wyczuwalną wilgoć i ruch powietrza; 
- akustyka przestrzeni poeksploatacyjnych, zwłaszcza obszernych komór, oraz całkowita izolacja od zewnętrznych źródeł emitujących dźwięki;

- niska promieniotwórczość naturalna środowiska podziemnego w kopalniach soli, związana między innymi ze śladową zawartością radonu w powietrzu oraz innych pierwiastków promieniotwórczych w skałach solnych stanowiących otoczenie przestrzeni eksploatacyjnych;

- szczelność złóż solnych, wynikająca z plastycznych właściwości soli;

- zazwyczaj ścisły i nierozerwalny związek elementów kopalni soli z zabudową miejską, wyraźnie widoczny w wielu historycznych miastach solnych, gdzie układ miasta pokrywa się w planie z układem kopalni, a zespoły szybowe znajdują się wewnątrz obszarów śródmiejskich lub w ich bezpośrednim sąsiedztwie.

A)

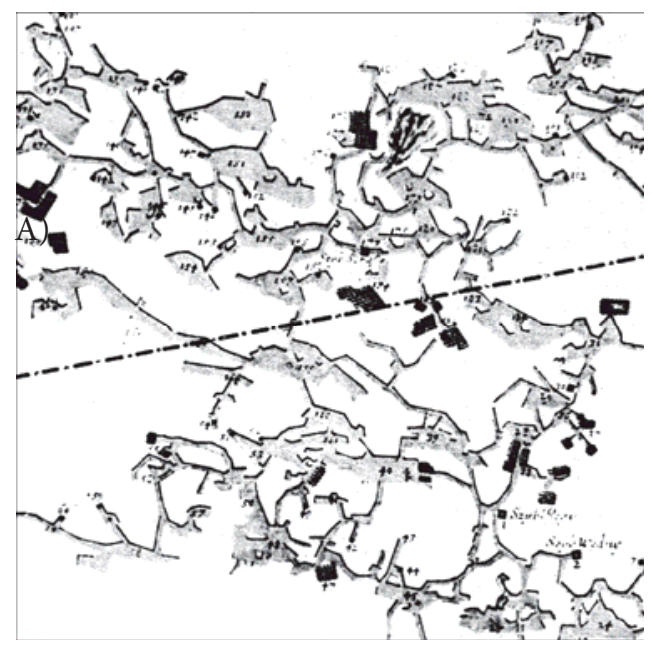

B)

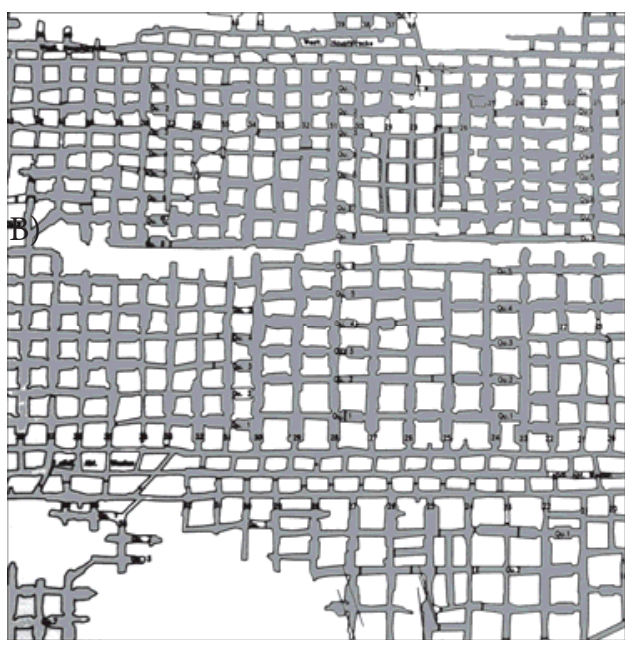

Fig. 1. Różne formy wyrobisk solnych w kopalniach podziemnych: A) Forma organiczna w kopalniach historycznych - przykład Wieliczki (Rajnich et al. 1988 - Załącznik 2). B) Regularna forma geometryczna w kopalniach współczesnych - fragment planu jednego z poziomów kopalni soli kamiennych i potasowych w Merkers, Niemcy (opracowanie własne na podstawie materiałów ekspozycji w podziemnym muzeum kopalni soli „Merkers”)

Fig. 1. Various forms of salt workings in underground mines: A) Organic form of historical mines an example Wieliczka Salt Mine (after Rajnich R. et al. 1988 - Appendix 2). B) Right: The regular geometrical form in the contemporary mines - a fragment of map, one of the levels of the potash salt in Merkers, Germany (graphic design: the author, based on materials of exposure in an Underground

Salt Mine Museum "Merkers")

Wymienione cechy wyrobisk solnych stanowią zbiór uwarunkowań dla różnych kierunków i możliwości funkcjonalnej adaptacji kopalni soli na nowe cele. Kierunki te zestawiono w tabeli 1, przypisując każdej funkcji grupę czynników i uwarunkowań decydujących o możliwościach adaptacyjnych. 


\section{Tabela (Table) 1}

Uwarunkowania współczesnej adaptacji wyrobisk solnych Determinants of contemporary adaptation of salt workings

\begin{tabular}{|c|c|c|c|}
\hline \multirow[b]{2}{*}{ Lp. } & \multicolumn{2}{|c|}{ Podstawowy kierunek adaptacji funkcjonalnej } & \multirow{2}{*}{$\begin{array}{c}\text { Główne czynniki } \\
\text { decydujące o możliwości adaptacji } \\
\text { funkcjonalnej } \\
\text { w danym kierunku }\end{array}$} \\
\hline & grupa funkcji & $\begin{array}{c}\text { elementy realizowane } \\
\text { w obrębie wyrobisk solnych }\end{array}$ & \\
\hline 1 & turystyka & podziemne trasy turystyczne & $\begin{array}{l}\text { - wartość historyczna wyrobisk solnych } \\
\text { - unikatowe walory widokowe } \\
\text { - niepowtarzalny nastrój panujący } \\
\text { w kopalni }\end{array}$ \\
\hline \multirow[b]{3}{*}{2} & \multirow[b]{3}{*}{ muzealnictwo } & trasy poznawcze & \multirow{3}{*}{$\begin{array}{l}\text { - wartość historyczna wyrobisk solnych } \\
\text { - niecodzienna sceneria podziemia } \\
\text { kopalni } \\
\text { - interesujące efekty świetlne } \\
\text { - zróżnicowanie przestrzeni } \\
\text { eksploatacyjnych } \\
\text { - pozostawianie w wyrobiskach urządzeń } \\
\text { i maszyn wyłączonych z użytkowania }\end{array}$} \\
\hline & & ekspozycje muzealne & \\
\hline & & parki maszynowe & \\
\hline 3 & $\begin{array}{l}\text { lecznictwo } \\
\text { uzdrowiskowe }\end{array}$ & podziemne sanatoria & $\begin{array}{l}\text { - lecznicze właściwości powietrza } \\
\text { nasyconego solą } \\
\text { - mikroklimat panujący w obrębie } \\
\text { wyrobisk solnych }\end{array}$ \\
\hline \multirow{4}{*}{4} & \multirow{4}{*}{ sport i rekreacja } & $\begin{array}{c}\text { masowe trasy biegowe } \\
\text { i rowerowe }\end{array}$ & \multirow{2}{*}{$\begin{array}{l}\text { - niecodzienna sceneria podziemia } \\
\text { kopalni } \\
\text { - stabilność warunków klimatycznych } \\
\text { - zróżnicowany układ przestrzenny } \\
\text { i rozciągłość wyrobisk }\end{array}$} \\
\hline & & $\begin{array}{l}\text { wyczynowe trasy biegowe } \\
\text { i rowerowe }\end{array}$ & \\
\hline & & trasy speleologiczne & $\begin{array}{l}\text { - złożona, organiczna forma wyrobisk } \\
\text { - ciasne przestrzenie połączone w długie } \\
\text { ciągi }\end{array}$ \\
\hline & & $\begin{array}{l}\text { boiska i urządzenia } \\
\text { sportowe }\end{array}$ & $\begin{array}{l}\text { - obecność dużych przestrzeni } \\
\text { eksploatacyjnych } \\
\text { - niezależność od warunków pogodowych }\end{array}$ \\
\hline 5 & rozrywka & $\begin{array}{l}\text { sale balowe, kręgielnie, } \\
\text { kluby itp. }\end{array}$ & $\begin{array}{l}\text { - niecodzienna sceneria podziemia } \\
\text { kopalni } \\
\text { - interesujące efekty świetlne }\end{array}$ \\
\hline \multirow[b]{2}{*}{6} & \multirow[b]{2}{*}{ kultura i sztuka } & galerie sztuki & $\begin{array}{l}\text { - niepowtarzalny nastrój panujący w kopalni } \\
\text { - specyficzne warunki oświetleniowe }\end{array}$ \\
\hline & & $\begin{array}{c}\text { sale koncertowe } \\
\text { i widowiskowe, } \\
\text { sceny teatralne i operowe }\end{array}$ & $\begin{array}{l}\text { - doskonała akustyka komór } \\
\text { eksploatacyjnych } \\
\text { - izolacja od czynników zakłócających }\end{array}$ \\
\hline
\end{tabular}


Table (Tabela) 1 cont. / cd.

\begin{tabular}{|c|c|c|c|}
\hline \multirow[b]{2}{*}{ Lp. } & \multicolumn{2}{|c|}{ Podstawowy kierunek adaptacji funkcjonalnej } & \multirow{2}{*}{$\begin{array}{c}\text { Główne czynniki } \\
\text { decydujące o możliwości adaptacji } \\
\text { funkcjonalnej w danym kierunku }\end{array}$} \\
\hline & grupa funkcji & $\begin{array}{c}\text { elementy realizowane } \\
\text { w obrębie wyrobisk solnych }\end{array}$ & \\
\hline 7 & $\begin{array}{l}\text { funkcja } \\
\text { reprezentacyjna }\end{array}$ & $\begin{array}{l}\text { sale konferencyjne } \\
\text { i bankietowe }\end{array}$ & $\begin{array}{l}\text { - niecodzienna sceneria podziemia kopalni } \\
\text { - obecność dużych przestrzeni } \\
\text { eksploatacyjnych }\end{array}$ \\
\hline \multirow[b]{2}{*}{8} & \multirow[b]{2}{*}{ kult religijny } & kościoły, kaplice i ołtarze & \multirow{2}{*}{$\begin{array}{l}\text { - niepowtarzalny nastrój panujący w kopalni } \\
\text { - niecodzienna sceneria podziemia kopalni } \\
\text { - izolacja od czynników zakłócających } \\
\text { - obecność dawnych obiektów kultu } \\
\text { religijnego }\end{array}$} \\
\hline & & $\begin{array}{l}\text { drogi krzyżowe i trasy } \\
\text { pielgrzymkowe }\end{array}$ & \\
\hline \multirow[b]{3}{*}{9} & \multirow[b]{3}{*}{$\begin{array}{l}\text { nauka } \\
\text { i edukacja }\end{array}$} & stanowiska dokumentacyjne & \multirow{2}{*}{$\begin{array}{l}\text { - wartość naukowa struktur geologicznych } \\
\text { - brak obudowy fragmentów ścian i stropów } \\
\text { - występowanie pierwotnych i wtórnych } \\
\text { zjawisk geologicznych }\end{array}$} \\
\hline & & trasy dydaktyczne & \\
\hline & & $\begin{array}{l}\text { podziemne laboratoria } \\
\text { badawcze }\end{array}$ & $\begin{array}{l}\text { - niska promieniotwórczość naturalna } \\
\text { - brak czynników zakłócających pracę } \\
\text { urządzeń } \\
\text { - obecność dużych przestrzeni } \\
\text { eksploatacyjnych }\end{array}$ \\
\hline 10 & archiwizacja & archiwa dokumentów & $\begin{array}{l}\text { - stabilność warunków klimatycznych } \\
\text { - konserwujące właściwości środowiska } \\
\text { - obecność dużych przestrzeni } \\
\text { eksploatacyjnych }\end{array}$ \\
\hline \multirow[b]{2}{*}{11} & \multirow[b]{2}{*}{ magazynowanie } & przechowalnie win & $\begin{array}{l}\text { - stałe warunki cieplno-wilgotnościowe } \\
\text { - brak dostępu światła słonecznego }\end{array}$ \\
\hline & & $\begin{array}{l}\text { magazyny surowców } \\
\text { strategicznych }\end{array}$ & $\begin{array}{l}\text { - względnie niskie koszty budowy } \\
\text { i eksploatacji } \\
\text { - mała wrażliwość na zagrożenia } \\
\text { zewnętrzne } \\
\text { - obecność dużych przestrzeni } \\
\text { eksploatacyjnych } \\
\text { - szczelność górotworu w obrębie złóż } \\
\text { solnych } \\
\text { - obojętność chemiczna i fizyczna soli }\end{array}$ \\
\hline \multirow[b]{2}{*}{12} & \multirow[b]{2}{*}{ składowanie } & $\begin{array}{l}\text { składowiska odpadów } \\
\text { komunalnych }\end{array}$ & \multirow{2}{*}{$\begin{array}{l}\text { - szczelność górotworu w obrębie złóż } \\
\text { solnych } \\
\text { - obecność dużych przestrzeni } \\
\text { eksploatacyjnych } \\
\text { - izolacja od środowiska zewnętrznego } \\
\text { - możliwość wykorzystania odpadów } \\
\text { jako materiału podsadzkowego }\end{array}$} \\
\hline & & $\begin{array}{l}\text { składowiska substancji } \\
\text { toksycznych } \\
\text { i promieniotwórczych } \\
\text { odpadów }\end{array}$ & \\
\hline
\end{tabular}


Dane zestawione w tabeli pokazują, że współczesna adaptacja kopalni soli może przebiegać w różnych kierunkach, a możliwości poprzemysłowego wykorzystania kopalni zależą przede wszystkim od zróżnicowanych cech wyrobisk górniczych. Wśród tych cech największe znaczenie we współczesnych działaniach adaptacyjnych ma kształt systemu wyrobisk oraz dominująca forma przestrzeni podziemnych. Dla większości wskazanych kierunków adaptacji, w tym: lecznictwa uzdrowiskowego, kultury i sztuki, rozrywki, ale także podziemnego magazynowania i składowania, istotna jest obecność obszernych komór wyrobiskowych - przestrzeni typowych dla współczesnych kopalni z regularnym układem wyrobisk, drążonych w złożach o stosunkowo prostej budowie geologicznej.

Jednocześnie cechą sprzyjającą adaptacji nieczynnych kopalni soli do pełnienia funkcji związanych z turystyką, muzealnictwem, kultem religijnym, sportem i rekreacją jest atrakcyjność wyrobisk górniczych, zwłaszcza wartość historyczna i walory widokowe, które w znacznym stopniu wynikają ze złożonej budowy geologicznej oraz organicznego, nieregularnego układu wyrobisk, którego elementem dominującym są wąskie i kręte korytarze.

Istotnym czynnikiem, decydującym o możliwości przystosowania wyrobisk solnych do pełnienia nowych funkcji, są również relacje przestrzenne kopalni i zabudowy miast górniczych. Ścisły związek tych elementów przemawia za udostępnianiem kopalni soli turystom, kuracjuszom, pielgrzymom, sportowcom i innym grupom użytkowników korzystających z usługowej oferty kopalni. Jednocześnie wyrobiska solne w kopalniach słabo powiązanych z przestrzenią miejską mogą być w większym zakresie wykorzystywane do tworzenia laboratoriów naukowych oraz podziemnych archiwów, magazynów i składowisk, a więc przystosowane do pełnienia funkcji, które nie wiążą się z koniecznością masowego udostępniania wyrobisk górniczych.

\section{SKUTKI WSPÓLCZESNYCH PRZEKSZTALCEŃ NIECZYNNYCH KOPALNI SOLI}

Analizując skutki współczesnych przekształceń wyrobisk solnych w nieczynnych kopalniach soli, należy zwrócić uwagę na to, że przekształcenia te wpisują się w dwa zasadnicze kierunki działań, tj.:

- nieodwracalną likwidację całości lub znaczącej części podziemnych wyrobisk górniczych, przez ich zatopienie lub podsadzenie różnego rodzaju materiałami, w tym: skałą płoną, piaskiem, żużlem, ale także odpadami;

- adaptację wybranych wyrobisk solnych do nowych potrzeb, z wprowadzeniem jednej lub kilku funkcji użytkowych, oraz częściową likwidację tych przestrzeni poeksploatacyjnych, których wykorzystanie wydaje się niecelowe dla przyjętego kierunku adaptacji (Fig. 2).

Badania kopalni soli w Europie pokazują, że możliwe jest czasowe łączenie wskazanych powyżej kierunków działań w obrębie jednego obiektu, tak jak to ma miejsce np. w niemieckiej kopalni soli „Glückauf-Sondershausen”. Kopalnia ta jest obecnie obiektem wielofunkcyjnym, wykorzystywanym między innymi do celów turystycznych, muzealnych i sportowych. Jednocześnie, prowadzony jest proces likwidacji nieczynnych wyrobisk górniczych, głównie przez podsadzanie odpadami, również niebezpiecznymi (Barchański 2004). 


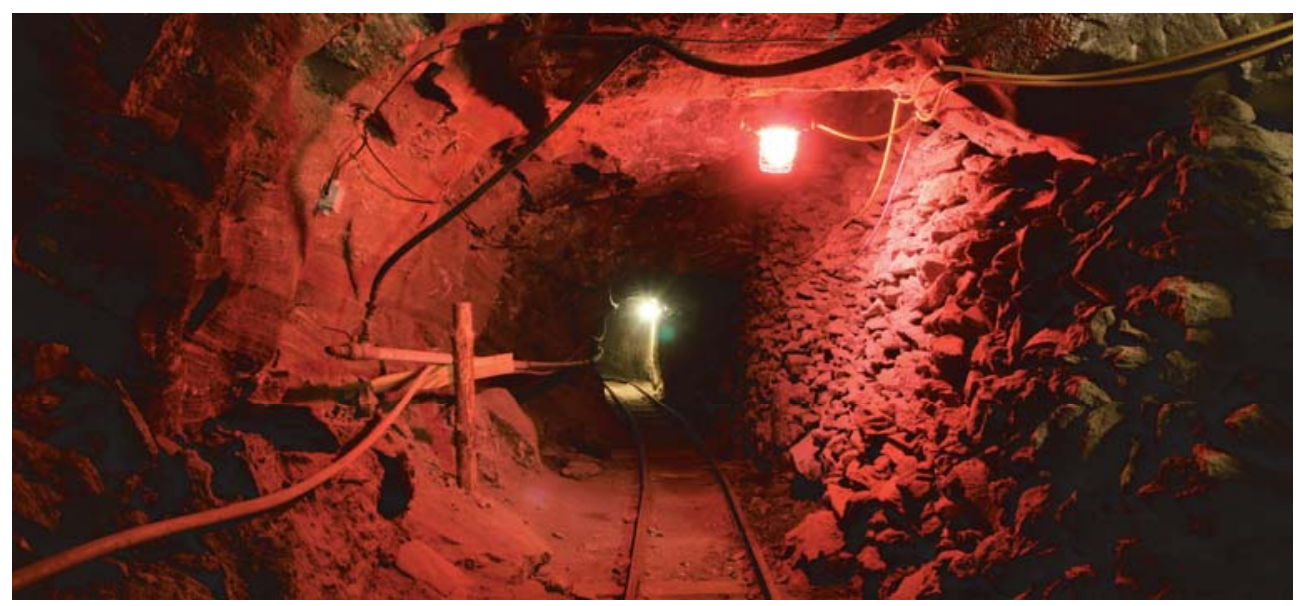

Fig. 2. Jedno z wielu stanowisk likwidacyjnych w obrębie wyrobisk solnych bocheńskiej kopalni, założone w rejonie zejścia „Lichtenfels” na poziom VI - „Sienkiewicz” (fot. autor)

Fig. 2. One of the many of liquidated underground excavations in Bochnia Salt Mine, "Lichtenfels" Gallery, VI Level "Sienkiewicz" (photo by author)

Trwała i całkowita likwidacja wyrobisk solnych dotyczy wielu kopalni soli na terenie całej Europy, między innymi we wschodniej Ukrainie i Dolnej Saksonii w Niemczech.

O zaniechaniu adaptacji funkcjonalnej i przystąpieniu do wypełniania wyrobisk górniczych po zakończeniu przemysłowej działalności kopalni mogą decydować różne uwarunkowania, wśród których najczęściej wymienia się:

- względy ekonomiczne, tj. wysokie koszty bieżącego utrzymywania wyrobisk solnych;

- aspekty techniczne, związane z brakiem możliwości zapewnienia bezpieczeństwa ludziom przebywającym w wyrobiskach, obsługi komunikacyjnej (poziomej i pionowej), wentylacji, łączności itp.;

- konieczność zmniejszenia niekorzystnego oddziaływania kopalni na otoczenie, w szczególności ograniczenie deformacji powierzchni terenu, zniszczeń istniejącej zabudowy i elementów oraz degradacji elementów środowiska naturalnego (wód podziemnych i powierzchniowych, gleb, szaty roślinnej);

- ryzyko wystąpienia katastrofy górniczej, która może się wiązać z poważnym zagrożeniem dla ludzi i zabudowy, zwłaszcza w miastach przestrzennie powiązanych z systemem wyrobisk górniczych.

Niezależnie od przyczyn rozpoczęcia procesu likwidacyjnego, zatopienie lub podsadzenie kopalni soli zawsze wiąże się z nieodwracalnym zniszczeniem wartości zachowanych w wyrobiskach solnych, w tym niespotykanych gdzie indziej walorów widokowych, a także uniemożliwia naoczną obserwację i badanie interesujących zjawisk geologicznych. Potwierdza to przykład kopalni soli „Solno” w Inowrocławiu, której likwidacja prawdopodobnie ocaliła miasto przed skutkami górniczej katastrofy, ale jednocześnie oznaczała 
zagładę obiektu podziemnego o charakterze unikatowym w skali całego świata. Historia kopalni „Solno” oraz innych jej podobnych pokazuje, że likwidacja wyrobisk solnych eliminuje z przestrzeni miast górniczych znaczący element ich atrakcyjności i historycznej tożsamości.

Proces likwidacyjny wyrobisk podziemnych determinuje również kierunek przekształceń elementów związanych z działalnością kopalni, usytuowanych na powierzchni terenu. Zakończeniu działalności górniczej towarzyszy zazwyczaj rozbiórka zabudowy i demontaż elementów infrastruktury służącej obsłudze kopalni, tak jak miało to miejsce w niemieckim mieście górniczym Bad Salzdetfurth. W wielu ośrodkach górnictwa solnego, jak na przykład w Kałuszu na Ukrainie czy wielkopolskim Wapnie, poprzemysłowa zabudowa nie została wprawdzie rozebrana, ale od czasu zamknięcia kopalni nie jest użytkowana, co powoduje jej stopniową degradację techniczną i estetyczną (Fig. 3).

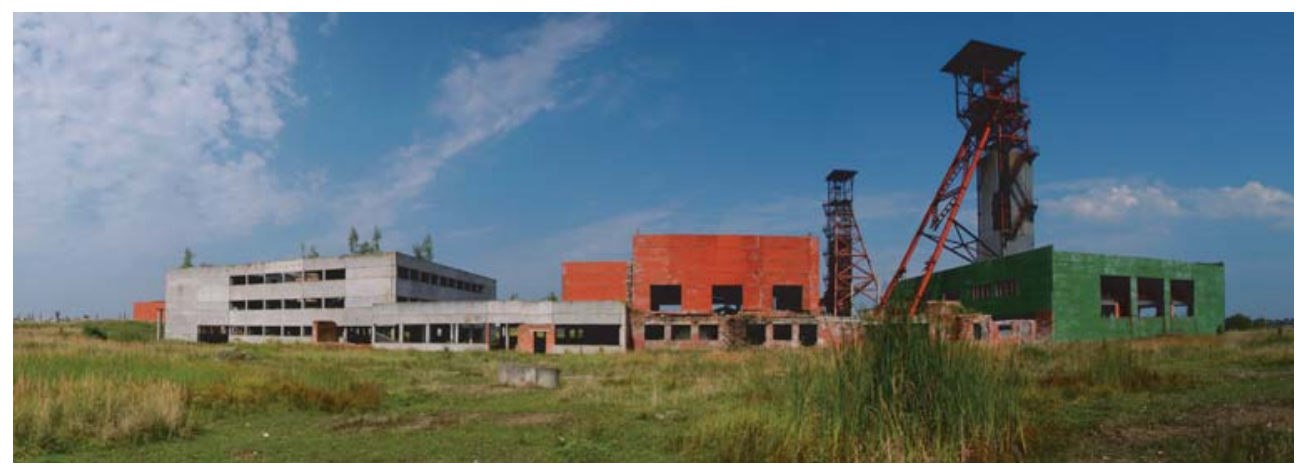

Fig. 3. Opuszczone, częściowo rozebrane nadszybie ukraińskiej kopalni soli w Kałuszu, w obwodzie iwanofrankowskim (fot. autor)

Fig. 3. The abandoned, partially demolished buildings of shafts in the Potash Salt Mine in Kalush (Ukraine) (photo by author)

Likwidacja podziemnych wyrobisk górniczych, nie tylko solnych, jest w Polsce regulowana obowiązującymi przepisami ustawy Prawo geologiczne i górnicze. Przepisy te nakazują po zakończeniu eksploatacji kopaliny: „(...) zabezpieczyć lub zlikwidować wyrobiska górnicze oraz obiekty i urządzenia zakładu górniczego (...)”, a także „(...) przedsięwziąć niezbędne środki w celu ochrony środowiska oraz rekultywacji gruntów i zagospodarowania terenów po działalności górniczej”. Należy jednak wyraźnie podkreślić, że w świetle przywołanego zapisu prawa podjęcie decyzji o zakończeniu przemysłowej działalności i postawienie kopalni w stan likwidacji nie musi oznaczać konieczności zlikwidowania całości wyrobisk ani istniejących elementów infrastruktury i zabudowy górniczej znajdujących się na powierzchni terenu.

Całkowita likwidacja nieczynnych kopalni soli jest zazwyczaj działaniem nieuniknionym, zdeterminowanym obiektywnymi uwarunkowaniami. Jednak w wielu przypadkach rozwiązaniem alternatywnym względem procesu likwidacyjnego wyrobisk jest możliwość 
ich adaptacji funkcjonalnej, prowadzonej zgodnie z uwarunkowaniami technicznymi i finansowymi. W zależności od przyjętego kierunku wykorzystania kopalni jako obiektu poprzemysłowego przebudowa i zagospodarowanie wyrobisk solnych dla współczesnych potrzeb może mieć zróżnicowany wpływ na miasta solne. Rozpatrując wyrobiska górnicze jako specyficzną przestrzeń urbanistyczną, należy podkreślić wpływ sposobu przebudowy kopalni na ogólną dostępność tych wyrobisk.

Wśród różnych kierunków współczesnej adaptacji podziemnych przestrzeni eksploatacyjnych w kopalniach soli można wyróżnić trzy podstawowe grupy:

- kierunki umożliwiające swobodny i w zasadzie nieograniczony dostęp do wyrobisk solnych różnym grupom użytkowników, w tym adaptacja kopalni do funkcji związanych z turystyką, lecznictwem uzdrowiskowym, sportem i rekreacją, kulturą, sztuką, muzealnictwem, kultem religijnym i edukacją, a także częściowo nauką;

- kierunki wymagające znacznego ograniczenia dostępności wyrobisk solnych, obejmujące przebudowę kopalni soli i ich adaptację na archiwa oraz laboratoria badawcze;

- kierunki wymuszające całkowitą izolację przestrzeni wyrobiskowych, związane z przekształceniem kopalni na podziemne magazyny różnych substancji oraz składowiska odpadów, w tym materiałów radioaktywnych.

Kierunki adaptacji wymienione w pierwszej grupie służą wyeksponowaniu wartościowych elementów salinarnych oraz utrzymaniu ich znaczącej roli, co sprzyja zachowaniu tożsamości miast i regionów solnych, a także wzmocnieniu ich atrakcyjności. Kierunki te wzajemnie się uzupełniają i mogą być łączone w obrębie jednego systemu wyrobisk. Jednocześnie, funkcje zaliczone do dwóch pozostałych grup wiążą się z koniecznością ograniczenia dostępu do całości lub części wyrobisk górniczych. Uruchamianie podziemnych laboratoriów badawczych, magazynów lub składowisk utrudnia, a nawet całkowicie uniemożliwia wielokierunkową adaptację kopalni soli. Funkcjonowanie takich obiektów nie służy również eksponowaniu walorów zachowanego dziedzictwa salinarnego i może prowadzić do osłabienia tożsamości górniczych miast salinarnych oraz zaniku ich specyficznych cech. Należy również podkreślić, że wszystkie współczesne kierunki zagospodarowania nieczynnych kopalni soli, niezależnie od wpływu na dostępność wyrobisk, mogą mieć duże znaczenie gospodarcze i być uzasadnione z ekonomicznego punktu widzenia.

\section{PODSUMOWANIE I WNIOSKI}

Na podstawie powyższych rozważań można sformułować wniosek, że współczesne przeobrażenia wyrobisk solnych mają duży wpływ nie tylko na obecny stan przemysłu solnego, ale również - a może przede wszystkim - na jakość przestrzeń miast górniczych, związanych z podziemnymi kopalniami soli. W obliczu powszechnego zjawiska, jakim jest likwidacja zakładów górniczych eksploatujących sól w wielu regionach salinarnych Europy, istotne jest spojrzenie na systemy wyrobisk solnych jako na specyficzną przestrzeń miejską, posiadającą wyjątkowe walory i możliwą do adaptacji do nowych, ekonomicznie opłacalnych funkcji. W tym kontekście decyzja o likwidacji kopalni soli, polegającej na całkowitym 
i trwałym wypełnieniu wyrobisk poeksploatacyjnych, powinna być podjęta jako rozwiązanie ostateczne, determinowane ważnymi i obiektywnymi okolicznościami.

Dla zachowania atrakcyjności i tożsamości górniczych miast solnych optymalnym kierunkiem przekształceń nieczynnych kopalni soli jest ich poprzemysłowa przebudowa i wykorzystanie dla współczesnych potrzeb. Skutki adaptacji wyrobisk górniczych w tych kopalniach nie są jednak obojętne dla przestrzeni miejskiej i ściśle zależą od przyjętego sposobu zagospodarowania kopalni. W celu ochrony oraz wyeksponowania wyjątkowych wartości zachowanych w wyrobiskach solnych konieczna jest adaptacja funkcjonalna zapewniająca możliwie swobodny dostęp do podziemnej części kopalni różnym grupom użytkowników. $\mathrm{Z}$ tego punktu widzenia przekształcanie wyrobisk górniczych w podziemne składowiska, magazyny, archiwa, a także laboratoria naukowe wydaje się zmniejszać atrakcyjność miast i choć pozwala na utrzymanie części wyrobisk solnych, eliminuje ich znaczenie jako przestrzeni urbanistycznej.

\section{LITERATURA}

Barchański B., 2004. Dobór bentonitowej bariery geotechnicznej umożliwiającej wykorzystanie odpadów niebezpiecznych do podsadzania wyrobisk poeksploatacyjnych - doświadczenia zagraniczne (kopalnia Sondershausen RFN). Górnictwo i Geoinżynieria, $28,4 / 1,27-42$.

Czapowski G., Sadowski A., Misiek G. \& Kolonko P., 2004. Możliwości niekonwencjonalnego wykorzystania walorów przyrodniczych i technicznych Kopalni Soli Kłodawa. Racjonalne sposoby wykorzystania złóż solnych - materiały konferencyjne IX Międzynarodowego Sympozjum Solnego „Quo Vadis Sal”, Bochnia 2004, 28-30.

Czapowski G. \& Tomassi-Morawiec H., 2006. Wykształcenie, geochemia, geneza i kierunki zagospodarowania cechsztyńskich pokładowych soli kamiennych na obszarze Lubińsko-Głogowskiego Okręgu Miedziowego. Pokładowe złoża soli w Polsce - materiały konferencyjne XI Międzynarodowego Sympozjum Solnego „Quo Vadis Sal”, Szklarska Poręba 2006, 7-10.

Kunstman A., Poborska-Młynarska K., Lepiarz J. \& Urbańczyk K., 2005. Wstępne koncepcje likwidacji Kopalni Soli „Kłodawa” na podstawie doświadczeń górnictwa solnego. Przyszłość podziemnego magazynowania w złożach soli - materiały konferencyjne X Międzynarodowego Sympozjum Solnego „Quo Vadis Sal”, Ciechocinek 2005, 69-71.

Markiewicz A., Pytel W. \& Zalewska A., 2006. Koncepcja wybudowania Laboratorium Polskiej Fizyki Cząstek w złożu najstarszej soli kamiennej na terenie LGOM. Pokładowe złoża soli w Polsce - materiały konferencyjne XI Międzynarodowego Sympozjum Solnego „Quo Vadis Sal”, Szklarska Poręba 2006, 49-53.

Marx H., Lack D. \& Krauke W., 2005. Substantial Aspects of the Recycling of Industrial Wastes as Backfilling Material in Salt Mines. Materiaty konferencyjne Mining and Sustainable Development - 20th World Mining Congress \& Expo 2005, Teheran, Iran.

Rajnich R., Siembab J. \& Sosna A., 1988. Mapy górnicze - część II. Wyd. Śląsk, Katowice. Ustawa z dnia 4 lutego 1994 r. Prawo geologiczne i górnicze. Dz. U. 1994 r. Nr 27, poz. 96. 


\section{Summary}

One important issue in the discussion on the current state and the future of salt mining is the possibility of utilizing mining excavations after termination of mines activity (Tab. 1). In the process of adapting such mines for new functions, salt excavations are usually treated as industrial areas, almost inaccessible and isolated from the environment. According to such approach, an optimal direction of utilizing salt excavations is seen in underground storing and warehousing, especially, economically cost-effective storage of various wastes, used also as a backfilling material. At the same time, many salt mines are being liquidated by workings' backfilling and demolition of land surface mine infrastructure (Figs 2, 3).

However, according to studies on numerous salinar towns in Europe, salt mines should not be treated only as mining facilities, standalone from the area. An analysis of numerous examples shows that salt mines, both in their underground and ground parts, can be strongly connected with the town areas and form joint systems with urban areas. In such approach, salt excavations can be perceived as urban areas, which can serve urban functions as well. Thus, it is essential in the process of modern reconstruction and adaptation of inactive mining excavations to consider a level of relations between a mine and urban area and to go by the superior need of preserving and exposing specific traits of salt mines and also to aim at the most possible maintenance of a general access to the most attractive mining excavations (Fig. 1). Establishing a proper utilizing offer, alternative to underground storage functions, can be also economically justified but most of all, according to the rule of sustainable development, it shall enable maintaining a specific cultural heritage and mining identity of salinar towns 